\title{
3 PROJECTS, PARTNERS AND POLITICS
}

\section{Peter Ninnes}

As I observed in the previous chapter, attendance at the Beijing forum by two of Leitana Nehan's founders, Helen Hakena and Agnes Titus, had a major impact on the conceptualisation, direction and focus of the organisation's work. In this chapter I describe the formal establishment of Leitana Nehan as an independent NGO. I then examine how it became involved in a number of key peace-building projects, the establishment of a range of important partnerships designed to facilitate the initiation and maintenance of peace, and its ongoing efforts to find a political solution to the Bougainville crisis. This middle period of Leitana Nehan's history, roughly 199599, expanded the founders' experience in managing small to mediumsized projects, a track record that allowed Leitana Nehan to tender successfully for the large projects that have sustained the organisation and its work.

In early 1995, Helen, Alina and Brenda had all been elected to the PCW executive-Alina as vice-president, Helen as secretary, and Brenda as treasurer-but they found that this actually limited the work they could do with Leitana Nehan. The PCW at the time was hierarchical in its decision-making processes, and the president tended to vet all ideas and proposals for action. As a result, the Leitana Nehan founders had difficulty getting funding for the courses and programs they wanted to run. At the same time, they perceived the PCW as being stagnant and wary of involvement in any activities that appeared too 'political'. They also felt that factions in the PCW were threatened by the presence of some of the Leitana Nehan founders on the 
executive, believing their appointments to be based on political decisions. In fact, Agnes recalled that Brenda and Helen were not invited to any executive meetings for six months at one stage. They tendered their resignations, but Agnes asked them to reconsider and took them to a PCW meeting with the president and a government adviser. Agnes asked the president to reconsider their resignations, but the president refused to do so. Whereas the PCW was unwilling to speak out on women's issues, the Leitana Nehan founders saw many problems arising from the conflict that needed to be addressed. These included addressing violence, abuse by the armed forces, lack of schooling for children, and lack of respect for people's rights, helping young people think about their future, and meeting women's and children's needs. As a result, when Agnes and Helen returned from Beijing, and Alina, Brenda and Helen all resigned from the PCW executive, they began moves to establish Leitana Nehan formally as an NGO by registering it with the Investment Promotions Authority in Port Moresby.

One of the first activities that Leitana Nehan organised after the Beijing conference the 'silent march' in Buka town, timed to coincide with the Bougainville show, which was held in Buka that year. ${ }^{1}$ More than 1,000 women participated in protest against the war and the use of rape as a weapon. This march occurred in defiance of the state of emergency in place at the time. The PNGDF stopped the marchers twice, attempting to arrest the march leaders. When asked 'who is your leader?' The women replied 'all of us are leaders. We all own the march'. The soldiers could not arrest all of them, so they arrested noone. As Helen recounts,

[w]e knew the prime minister was in Buka [at the time of the march] and the media would be out in force. We walked silently carrying banners we had sewn by hand, with messages of peace. The media saw us and told our story to the rest of Papua New Guinea. Our sisters in Rabaul were so moved by the story that they organised a boat and sailed through the Buka passage, singing peace songs. There was shooting on both sides of the passage before the women arrived. As they sailed though, the shooting stopped. Their singing stopped the guns (Hakena 2003:n.p.).

One of the major roles that Leitana Nehan has played in Bougainville during the last ten years has been to organise gatherings of young people to discuss issues relevant to peace and development 
on Bougainville, and to help youth deal with the trauma of the war. The first of these youth 'mobilisations' occurred at Gogohe village, on Buka Island, in November 1996 with less than 50 attendees. A similar event was held at Hahela on Buka in early 1997. These two small gatherings turned out to be a trial run for future events. According to Tonissen (2001:33), these mobilisations helped participants understand how violence is 'described, understood and "explained", by men and women separately, in order to examine how [agencies] may develop policies and practices against violence'.

In November 1997 (and following the signing of the truce), Leitana Nehan organised a youth mobilisation using funds supplied by Community Aid Abroad and Oxfam. Although Leitana Nehan had budgeted for 200 attendees, 784 young people showed up, coming mainly from Nissan, Buka, Tinputz, Saposa and Sipai. Fortunately, the Ministry for Bougainville Affairs donated K5,000 towards food and transport costs for the extra delegates. A number of prominent politicians attended the mobilisation, including the Honourable Michael Somare, the Honourable John Momis, the Honourable Michael Laimo, the Honourable Michael Ogio and Joseph Kabui, the Vice-President of the Bougainville Interim Government. The attendees represented all denominations and included combatants from both sides. The meeting was organised through Leitana Nehan's various networks, and its goals were communicated in only vague terms, in order not to alarm the authorities or raise the suspicions of the PNGDF. The meeting lasted five days. On the first day, the organisers encouraged the young people to write stories, songs and poems about life on Bougainville and what they wanted for Bougainville. On the second day, the young people performed songs and dances about their life, particularly during the crisis and in the bush behind the blockade. On the third evening, participants were asked to come and read their poems at the microphone in front of the crowd, moving many of the listeners to tears. Trust was being built-these activities were a way of getting the young people to relate with each other. On the fourth day the participants spent time in groups discussing their fears, and the fifth evening was spent sharing and listening to each other's stories. Each 
day started with lotu (worship), and the program ended with a large church service, focusing on young people's issues, attended by participants and local villagers.

The Leitana Nehan staff were assisted at this first large youth mobilisation by two priests, Father Saris and Father Boniface, as well as Catholic Family Life workers, other church workers, George Lesi, Jessie Walo, Gordon Gunan and Jennifer Hasop. One long-term benefit of this first mobilisation was that Leitana Nehan began recruiting its first volunteers, but the mobilisation also represented a shift in focus for Leitana Nehan. Rather than simply focusing on humanitarian relief work, these mobilisations were a form of peace and community building. As Helen observed in an interview with the New Internationalist in 2003,

[w] b brought young men together with young women to talk about the effects of the blockade and speak openly about the use of rape and guns. The result was a common understanding of each other's fear and a resolve to build awareness among the community (Hakena 2002:n.p.).

A second major youth mobilisation was held in 12-19 November 1999. Again the venue was the Hahela Youth Centre. This time about 2,000 young people attended. The meeting was supported by a K5,000 grant from Community Aid Abroad and Save the Children Fund and K5,000 from the Honourable Michael Somare. The program followed a format similar to the first event, but had more formal input and teaching on topics such as personality integration, gender awareness, women's rights, and alcohol and drug awareness. A third but smaller youth mobilisation was held at Tinputz, on Bougainville Island, in 2000. It was more focused, and was attended by a selection of 88 youth leaders. Topics covered included proposal and report writing, as well as gender and alcohol awareness and human rights training. As was the case with the first major youth mobilisation, the events in 1999 and 2000 turned out to be fertile ground for recruiting volunteers for Leitana Nehan's work.

The personal and professional development that had characterised Helen and Agnes' attendance at the Beijing forum was an early example of the ways Leitana Nehan has used national and international conferences, meetings and workshops to expand its 
founders' and volunteers' skills, understandings and perceptions. In the mid to late 1990s, Leitana Nehan staff participated in many such events. Alina travelled to Tonga in February 1996 to attend a two-week conflict resolution workshop, and in February 1997 she attended an NGO conference at Vunapope, East New Britain. Three months later she attended the Diocesan Directors' Secretariat Conference in Kavieng, New Ireland, before heading to Sydney for three months for trauma counselling training. In October 1997, Alina attended a conference in Chiang Mai, Thailand, on refugee women in armed conflict situations. The following month she attended the Asia Pacific Development Workshop also held in Chiang Mai. In 1998, Alina attended a three-month course on counselling in drug and alcohol addiction held in Sydney, and in 1999 she spent a month in Australia promoting and explaining Leitana Nehan's work.

Helen was funded by Oxfam New Zealand to undertake counsellor training in Suva, Fiji, in 1996, and in 1997 she attended a review of Community Aid Abroad and Oxfam programs in the Pacific, held at Nymikum, Maprik, in the East Sepik Province of Papua New Guinea. In the same year, Helen attended the Beneath Paradise Pacific Women's documentation project in Suva (funded by IWDA). One outcome of this project was the formation of the Pacific Women Against Violence Network, of which Leitana Nehan remains a member. Helen also attended the international workshop on strategies and services to address gender violence, held in the Philippines. In 1998, Helen and Elizabeth Behis undertook four weeks of counsellor training at the Fiji Women's Crisis Centre in Suva, Fiji, and towards the end of that year Helen attended the Eighth World Council of Churches Assembly in Zimbabwe. Helen's professional development continued in 1999 with a World Vision-funded trip to Melbourne, during which she visited a telephone counselling service, attended the international conference on the use of children as soldiers, participated in a 16-day activism workshop at Ross House in Fitzroy, and attended the international commission of jurists conference at the University of Melbourne. Also in 1999, Helen attended a conference in Malaysia on women in armed conflict situations, funded by the Asian and Pacific Development Centre. 
In 1998, Agnes attended the Australian Council for Overseas Aid meeting in Canberra and toured around Australia talking about the crisis, funded by IWDA. Agnes' work for Leitana Nehan, however, was limited during this period because she was also a member of the Bougainville Transitional Government, and had portfolio responsibilities. The fourth founder, Brenda Tohiana, was a founding member of the Buka Urban Council, in which she had been heavily involved since its inception in 1992. However, Brenda had a major role in setting up and managing Leitana Nehan's financial systems and accounts.

Among the other staff and volunteers from this period of time, Francis Botsia, one of the first Leitana Nehan volunteers, attended Integral Human Development training in Goroka in the Papua New Guinea highlands in 1996, and Elizabeth Behis, Francis Botsia and Leonard Mokela attended a similar program in Rabaul in 1997. These events provided training in conducting awareness programs, trainer development programs, and youth mobilisation programs. Francis Botsia and Jessie Walo attended a personality integration and conflict resolution course at Vunapope in 1997, while Bianca Hakena and Elizabeth Behis went to Fiji in 1999 for feminist counselling training at the Fiji Women's Crisis Centre, funded by Oxfam New Zealand. Late in 1999, Bianca and Yvonne Baito also attended a basic computer training course at the Commercial Training College in Lae, Papua New Guinea.

All of these travels were not without risk. The war continued until the truce was signed in 1997, but even after that the culture of violence that had developed and the large number of weapons in the community always posed a threat. As Helen recounted in an address to a symposium at the University of New England in 2003,

[o]n my way to a women's conference in Canberra in 1998 I was held at knifepoint at Port Moresby's Jackson Airport by two unknown persons and told to return to Bougainville. They knew that I was going to attend a conference in Australia where I was going to alert the world about the atrocities inflicted upon the people of Bougainville, especially on women and children. My personal belongings, including the videotapes and conference papers I was to present to the conference, were confiscated. They were returned a day later. I had to return to Bougainville for fear of being sexually abused or killed (Hakena 2003b:n.p.). 
In addition to these outside programs, Leitana Nehan facilitated a number of in-house or local staff-training workshops and programs, often run by outsiders. In 1997, Anne David from Oxfam conducted gender training workshops for Leitana Nehan volunteers. Father Makario conducted a trauma-counselling workshop at Hahela, which was attended by Kris Hakena, Helen, Agnes, Brenda, Alina and Delphine Lesi (whose husband was George Lesi). In 1998, Helen Rosenbaum of IWDA conducted a strategic-planning workshop with Leitana Nehan staff. The following year Dr Victor Storm, a senior psychiatrist, director of clinical services at Rozelle Hospital in Sydney, and Chair of the Royal Australian and New Zealand College of Psychiatrists, conducted workshops on mental health issues as part of a visit to Buka and Bougainville to hold consultations with health educators and community leaders. Leitana Nehan organised his visit, with support and advice from the PNG Division of Health. Agnes Titus, Melkio Dare (a nurse from Paruparu) and Aloysius Pukiene (a public health officer) accompanied Dr Storm on his tour, which included two workshops in Buka and others in Arawa and Buin.

During the second half of the 1990s, Leitana Nehan developed and further expanded its work in the provision of workshops and training for local communities. In 1996, Leitana Nehan secured funding from parliamentarian Michael Ogio to send 20 women to the Catholic Women's Conference in Chimbu, in the Papua New Guinea highlands. In the same year, Leitana Nehan also collaborated with the Catholic Family Life organisation to facilitate a personality integration course for Bougainville youth, and ran a community-mapping workshop at Hahela. The latter resulted from a proposal submitted to Oxfam and Community Aid Abroad, which together contributed K8,000 to cover costs. The workshop aimed to help young people identify problems in their communities and the local resources available to solve them. Some chiefs also attended, and the workshop was facilitated by five staff from Community Aid Abroad, including Julie Eagles, Stuart Watson, Anne David, Reiner Tegetmeier and Rebecca Fleisher.

Starting in 1996, Leitana Nehan worked with Theresa Postma from IWDA on a project entitled 'Working Towards Peace'. This program was funded by the AusAID and Non-Government 
Organisations Cooperation Program and addressed issues of violence and homebrew abuse (Tonissen 2001) in North Bougainville.

In 1998, Leitana Nehan held the first homebrew and violence against women awareness workshop in Tinputz Primary School, and began assembling its first volunteer team for the Strengthening Communities for Peace project (see Chapter 4). This first team comprised Ezekial Lames, Valentine Tur, Chris Sagolo, Samson Lino, Fabian Kotsin, Norman Tola, Linus Saram, Cecilia Francis and Clement Borats.

The following year, 1999, was an important year in the development of Leitana Nehan's programs and its influence on peace and community-building in Bougainville. The reach of the organisation started to extend beyond Buka and the nearby parts of Bougainville. Awareness programs were held for the first time in the Northwest district of Bougainville (Hahon, Sipai and Kunua). Furthermore, Francis Botsia and Ezekial Lames, Leitana Nehan volunteers who were both former members of the BRA, visited Paruparu in the no-go zone. This area was still controlled by Francis Ona and his troops and generally closed to outsiders. The aim of their visit was to assess recovery needs in the area (see Box 3.1).

A homebrew alcohol awareness program was run in Siwai, South Bougainville in late 1999, one of the 96 such programs run by the organisation that year as part of its Working Towards Peace program, reaching over 10,000 people. The popularity and value of Leitana Nehan's work was demonstrated also by the fact that in June 1999 the organisation held two gender awareness workshops in North Bougainville, funded by the British High Commission, attended by over 400 people. Leitana Nehan also started integrating HIV/AIDS awareness sessions into its programs at about this time, focusing on prevention and operating in an environment in which no reliable data was available about the extent of the disease in Bougainville. In 1999, counselling services continued to be provided, both in the community and in high schools, by which time the organisation had four counsellors-Helen Hakena, Alina Longa, Bianca Hakena and Elizabeth Behis. Most counselling cases concerned rape, domestic violence, sexual harassment or child abuse. 


\section{Box 3.1 From BRA to jail to peace-builder Francis Botsia}

I was in the BRA until 1990, when the chiefs did a reconciliation ceremony between some BRA and the PNGDF. But when I resigned from the BRA, the PNGDF went back on their word and arrested me and sent me to jail in Keravat, in Rabaul, to await trial. I waited for four years in Keravat, except for about nine months when I escaped and was on the run. When I finally came to trial, they decided to hold it in Buka, so they flew me to Buka on the Monday, the trial was on a Wednesday and I was released. The next day the Rabaul volcano erupted and destroyed the town.

I started working with Leitana Nehan after attending one of the youth mobilisations. I was the first president of the Bougainville Youth Association after the crisis. I was appointed at a meeting we had at Gogohe. Then Leitana Nehan started helping me get organised, with assistance from Family Life. I was involved with the youth, and Leitana Nehan helped me with the programs we were running. I saw that the Leitana Nehan programs really helped us, especially the ex-combatants. I got some of the hard-core ex-combatants and took them to the programs, and then we got them to talk to people attending about the impact of the program on them and about our life during the war.

To be honest, the awareness programs really bore a lot of fruit. When we did homebrew awareness we used frogs or we would cut open chickens' intestines and pour pure homebrew on them to show the effect of it. The homebrew would just cook the intestines completely.

I travelled to plenty of places during the crisis. Francis Ona invited us to go through the villages in the no-go zone when we were based in Paruparu. We went through those small villages up around Panguna, along with three women and two male volunteers. There was no access by car. We had to walk from Birempa up to Paruparu, which is quite a long walk. For those of us not used to walking so far, it took from 8 o'clock in the morning and we arrived at Paruparu at 5 o'clock in the evening. We set camp at Paruparu for a couple of days. I had to run a small training for the volunteers to clarify the aims of the program. From Paruparu we had to walk to Chaba river, and from there to Morone, which is up in the Panguna area, then back to Chaba. We did the Violence against Women program, the child abuse program, and the homebrew awareness program. From there we decided to come back from Panguna to Arawa, and we had a chance to catch a vehicle in Panguna or else we would have had to walk another two days to Arawa. Then we caught an Air Sankamap plane back to Buka. Actually we spent three weeks in the whole of the Panguna area, walking to one place, running an awareness workshop at night, sleeping there, then getting up and walking to the next place. 
A major new initiative in 1999 was the commencement of Leitana Nehan radio programs on peace and community development through the National Broadcasting Corporation station in Buka. The programs provide information on violence against women, international conventions such as the Convention on the Elimination of All Forms of Discrimination Against Women (CEDAW) and the Convention on the Rights of the Child (CRC), conflict transformation and good governance. Leitana Nehan estimates that the radio programs reached over 10,000 people in Bougainville and nearby Solomon Islands (Hakena 2005). One impact of the radio program in the early days was that people from the no-go zone started to come out to attend awareness workshops. For example, a chief from Bana sent five women to do one of the workshops.

The professional development, peace-building and community development activities described above came about through the generous contributions of a number of organisations and partners. Community Aid Abroad, Oxfam, the International Women's Development Agency (IWDA), the Australian Agency for International Development (AusAID), the Young Men's Christian Association, the New Zealand High Commission and the British High Commission, as well as local politicians and other community and family members all contributed either financially or in other ways to the success of the work being undertaken. For example, in 1999, Kris Hakena's brother, Stan Hakena, who is the Manager of the Keno Foundation, provided new office space for Leitana Nehan at a generous rental rate. Prior to this, the organisation had been in a small galvanised iron clad office in a building behind the City Pharmacy, having moved out from underneath the Hakena's home in Buka town in 1997. Also in 1999, Dr Storm donated an overhead projector, the Division of Health provided a television and video cassette recorder and the British High Commission funded a photocopier.

Further help came from the Truce Monitoring Group, put in place after the signing of the truce in 1998, which provided logistical support for Leitana Nehan's work. Of particular note, however, is the work of IWDA, which first had contact with Leitana Nehan in 
1994. In 1997, an IWDA representative, Helen Rosenbaum, developed a constitution and a strategic plan, formalising the existence of Leitana Nehan. Under its new constitution, Leitana Nehan had an executive and a board of directors (see Appendix 4). Helen Hakena became the Executive Director; Brenda, with her background in accounting, became the Financial Officer; while Agnes became the first Chair of the Board. Also in 1998, IWDA and Leitana Nehan jointly devised the Strengthening Communities for Peace project (see Chapters 4 and 5).

A third major focus of Leitana Nehan's work in the second half of the 1990s was political and involved contributing to peace-making at the local, national and international levels. Leitana Nehan was continuing to provide second-hand clothes for families in the care centres, and their reputation in this area led to an interesting encounter with Sam Kauna, military commander of the BRA. In 1996, Sam Kauna called Helen by radio from the no-go zone to ask for clothes for the BRA soldiers to go to the then current round of peace talks. Helen approached the Bougainville Transitional Government for permission, and the government gave her K3,000 with which she bought jeans and other items of clothing. Then Sam Kauna called back and told them how to find them in the bush. A helicopter flew the clothes in to the mountains. It returned loaded with fresh garden produce from the mountains and landed in the PNGDF hospital, which was located near the current Buka hospital site.

Agnes attended discussions about the Bougainville crisis held in Canberra in 1995, but the National Elections in Papua New Guinea in 1997 provided something of a circuit-breaker in the Bougainville crisis-Rabbie Namaliu was defeated, partly as a result of the Sandline crisis (Dorney 1998), and Bill Skate was elected. After the Truce Monitoring Group was formed, Agnes joined a small delegation representing the Bougainville Transitional Government (BTG) which went to Roroinang in the mountains in Central Bougainville to talk with Joseph Kabui, Vice-President of the Bougainville Interim Government (BIG). This was the first time that the BTG had met the BIG face-to-face, and the church in which the meetings took place was full of Bougainville Revolutionary Army (BRA) soldiers. 
In 1998, Helen and Agnes accompanied Rarua Skate, wife of new Prime Minister Bill Skate, on a visit to Kurai Village, in the Central District of Bougainville, to meet with women leaders of the Bougainville Revolutionary Army. Although it was a frightening prospect, Helen felt compelled to go, since women in that area remained fearful of travelling. The aim of the visit was to meet faceto-face for the first time and to share experiences from different sides of the crisis. Mainland women at that time viewed Buka women as enemies and sometimes felt that they had not suffered during the crisis simply because they were outside the PNGDF blockade. The meeting in Kurai, however, provided the opportunity to share issues such as lack of social services, high maternal and infant mortality, and abuse by the defence forces. The women listened to each other's stories and realised that they all wanted peace and an end to the war. The mainland women in the meeting comprised many women from the Bougainville Women for Peace and Freedom (BWPF) and the Bougainville Community Based Integrated Humanitarian Program (BOCBIHP), such as Josephine Sirivi, Lucy Madoi, Lucy Sinei and Ruby Mirinika. Josephine Sirivi (1998:57) left a brief account of the meeting, noting

[a]t this meeting we clearly stated our stand for peace and freedom and our belief for political independence. We discussed how important it is for us to determine our own needs and our preferred ways of implementing development, and we considered the potential for accepting invitations from our sisters in the north to visit them when BIG clearance could determine a suitable future time.

Agnes also visited Canberra in 1997 to address the members of the Truce Monitoring Group (TMG) about the Bougainville crisis, the needs of women and the importance of the TMG being unarmed and including women who could work with Bougainville women affected by the war. In 1999, the MV Doulos visited Buka and Kieta. This nautical bookshop travels around the eastern hemisphere, encouraging young people to read, providing access to a range of Christian and secular reading materials and conducting workshops on spiritual topics. Leitana Nehan promoted the visit among local schools and helped organise a space on shore-a building behind Judith Raban's Guesthouse in Buka town-for the ship's display. 
In early October 1999, the Minister for Foreign Affairs and Bougainville Affairs, the Honourable Michael Somare arrived in Buka for continuing discussions on the political future of Bougainville. Relatively few key women leaders were available to attend, their movements still constrained, and many mainland women still held concerns about the consequences of being seen in the presence of such a prominent PNG leader. Helen and Agnes attended the talks, which were held at Hani's Inn in Buka town.

Later the same month, a reconciliation meeting between Bougainville leaders was held on Nissan. Agnes participated in the meeting, as did George Lesi as a member of the Bougainville People's Congress (BPC), having earlier resigned as Provincial Administrator. The resulting 'Nehan Declaration' allowed the Bougainville leaders to negotiate with the PNG National Government to obtain the highest possible levels of autonomy in the short term and a referendum on independence in the long term. This meeting was followed by a round of negotiations between Papua New Guinea and Bougainville leaders in December 1999 at Hutjena United Church on Buka. George Lesi participated as a member of the Bougainville People's Congress. The Hutjena Accord indicated that the main issues for consideration were the issues of autonomy and a referendum, which had been part of the Nehan Declaration signed by Bougainville leaders on Nissan the previous month.

At the local level, a one-day reconciliation ceremony was staged at Hoko, Gogohe, Buka, between Bougainville People's Congress members from Buka and the Leitana Council of Elders (LCOE). This ceremony was necessary because the BPC was comprised mainly of BRA members, while the LCOE consisted primarily of the BRF. The conflict had caused deep divisions. Reconciliation was necessary so that the two groups could work together for peace and recovery. The ceremony was preceded by a number of speeches, including one given by Helen. The ceremony involved, among other things, the members of both bodies stepping over a live pig, walking under an arch of shell money and chewing betel nut together.

Other developments in that year also impacted on the work of Leitana Nehan. In November 1999, the regional member for 
Bougainville, The Honourable John Momis, won a court case in which he challenged the legality of the previous suspension of the North Solomon's Provincial Government. As a result, John Momis was reinstalled as Governor of Bougainville in a ceremony held on 29 December 1999, initiated by the Leitana Council of Elders and attended by the President of the Bougainville People's Congress, Joseph Kabui. This ceremony created a further sense of unity among the various factions to the conflict. It also cemented the legitimacy of the BPC government. Both of these events are significant because they created conditions in which Leitana Nehan could further develop and expand its work on Buka and the mainland.

The political work of Leitana Nehan at the local and national levels, and their work on peace and community development among young people came together in a one-day crusade held at Isa beachfront on 23 December 1999. Many young people attended from places such as Tinputz, Sipai, Selau, Kunua/Kereaka and Buka. Bishop Henk Kronenberg was the key speaker at the rally, and there were also speeches by various politicians. This event was important in the expansion of Leitana Nehan's work because it brought together Catholic, Uniting Church and Seventh-Day Adventist youth and leaders in a spirit of unity and a peaceful celebration of Christmas. In some quarters, Catholics had been blamed for the crisis, mainly because the Bougainville Provincial Government had prior to the crisis been composed mainly of Catholics and had been unable to prevent or avert the crisis. Such unity was important to Leitana Nehan, given its strong Catholic roots and its intention to promote peacebuilding across denominational barriers.

The mid to late 1990s saw Leitana Nehan continue some humanitarian relief work, but the signing of the Burnham peace accord in 1997 and the commencement of the ceasefire in 1998 shifted its work towards peace-building, including community and personal rehabilitation and reconciliation. The 1999 Leitana Nehan annual report estimates that in that year alone the organisation reached nearly 50,000 people through its awareness workshops, radio programs, print media articles and one-off events such as International Women's Day. Nonetheless, the demand for its work far outstretched 
its various sources of funding, while high travel costs and lack of transport and communication infrastructure also limited the work that could be done. Despite these constraints, during the second half of the 1990s, Leitana Nehan built up an unrivalled track record in program delivery, advocacy and training in Bougainville, leading to funding for major Bougainville-wide programs.

\section{NOTE}

1 Garasu (2002) relates, '[o]n their return from Beijing, women from northern Bougainville conducted a silent march in protest against the war, in defiance of the State of Emergency'. 